\title{
Rainfed winter wheat cultivation in the North German Plain will be water limited under climate change until 2070
}

\author{
Nikolai Svoboda*, Maximilian Strer and Johannes Hufnagel
}

\begin{abstract}
Background: We analysed regionalised ECHAM6 climate data for the North German Plains (NGP) in two time slots from 1981 to 2010 and 2041 to 2070.

Results: The annual mean temperature will increase significantly (by about $2{ }^{\circ} \mathrm{C}$ ) that will result in shorter growing periods since the sum of degree days until harvest will be reached earlier. Even if the amount of total precipitation does not change there appears to be a shift towards increased winter precipitation and thus noticeable reduced summer precipitation.
\end{abstract}

Conclusions: Through the example of winter wheat we show a future limitation of water availability if yields are to be maintained or even increase.

Keywords: Summer rainfall, Growing period, Resource efficient production systems

\section{Background}

Water is fundamental to plant growth, so the impact of climatic water availability on crop production is significant. Extreme yield drops in Europe in 2003 (loss of 13 billion Euros) were associated with an environmental temperature increase of nearly $6{ }^{\circ} \mathrm{C}$ above the long-term mean and below average precipitation of approximately $300 \mathrm{~mm}$ [17]. Many authors [9, 11, 12] show there is a general increase in winter precipitation, visible in predicted climate data. Meinke et al. [12] show an increase in winter precipitation with regional climate models, for North Germany, of $+22 \%$, but a decrease in summer of $-17 \%$. Thus, we could expect reduced summer rainfall and consecutively increased risk of yield losses due to increased water deficit of field crops. Aim of this study is to evaluate if there may arise serious problems and answer the following questions:

1. Is there a relevant change by comparing the status quo with current climate projections?

*Correspondence: Nikolai.Svoboda@zalf.de

Institute of Land Use Systems, Leibniz Centre for Agricultural Landscape Research, Eberswalder Straße 84, 15374 Müncheberg, Germany
2. Is there a shift towards winter rainfall in the NGP, and in particular in the study regions, as predicted in the literature?

3. Is there a trend to decreased and less steady rainfall during the summer growing period of winter wheat visible when evaluating current climate projections?

\section{Methods}

\section{Study area}

The North German Plain (NGP) covers the administrative units of Schleswig-Holstein, Mecklenburg Vorpommern, Lower Saxony, Brandenburg and parts of Saxony-Anhalt. As described in Dickinson [4] most of the area is less than $100 \mathrm{~m}$ in altitude, and only its zones of low hills reach more than $200 \mathrm{~m}$. Surface deposits are the results of glaciation. The general climate follows a gradient of increasing continentality from west (oceanic) to east (sub-continental). The mean annual temperature is comparable across the NGP but the western part has a temperature range, from annual minimum to annual maximum, of $16.4^{\circ} \mathrm{C}$ and the eastern part a range of $18.5{ }^{\circ} \mathrm{C}$. The western part of the NGP has a precipitation of $600-800 \mathrm{~mm}$ per year, while the eastern part 
has a smaller total of 500-600 mm [4]. Main field crops in terms of acreage in the NGP are winter wheat, winter rape, silage maize and winter rye. In the present study, Diepholz (DH) as the most western and Oder-Spree (OS) as the most eastern regions were investigated (Fig. 1). DH has a long-term (1981-2010) mean temperature of $9.6^{\circ} \mathrm{C}$ and $719 \mathrm{~mm}$ of precipitation (Fig. 2a). OS has $9.6^{\circ} \mathrm{C}$ and $568 \mathrm{~mm}$ in long term (Fig. 2b). In 2003, precipitation in $\mathrm{DH}$ was measured at $523 \mathrm{~mm}$ and $434 \mathrm{~mm}$ in OS, respectively. In DH, 2003 was the year with the lowest precipitation during the observation period (1981-2010).

\section{Crop}

Winter wheat is the most important crop in the NGP and, matching with Boogaard et al. [2], the dominant crop of Europe in terms of acreage. In DH, $16 \%$ of all cropping area is winter wheat (WW). In OS, the share is $7 \%$. The sowing date $\left(J D_{\mathrm{s}}\right)$ is September 15 as common in the NGP. Due to temperature as the main driver for physiological processes [1], the harvest date of winter wheat is essentially determined by cumulated temperature (heat sum), expressed in degree days (DD) [8]. Growth of winter wheat depends strictly on the air temperature [18].

\section{Modelling the harvest date and growing period}

The duration of the growing period $\left(V_{\text {per }}\right)$ is determined by:

$$
V_{\mathrm{per}}=J D_{\mathrm{h}}+\left(365 \frac{1}{4}-J D_{\mathrm{s}}\right)
$$

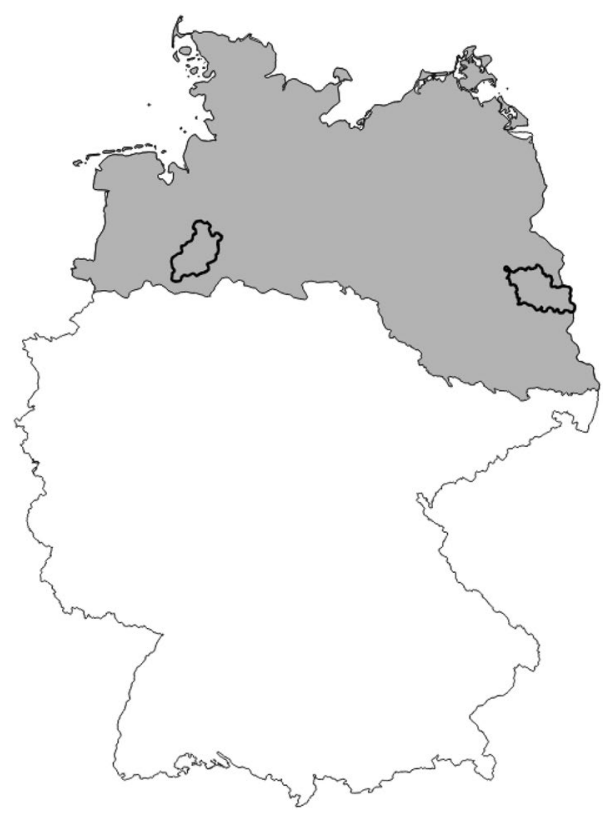

Fig. 1 The North German Plain (grey) and the study regions Diepholz (left) and Oder-Spree (right) with $J D_{\mathrm{h}}$ [day of year (DOY)] and $J D_{\mathrm{s}}$ [DOY] being the harvest and the sowing date, and $365 \frac{1}{4}$ denoting 365 days per year and 366 in the leap year, respectively. The harvest date $J D_{\mathrm{h}}$ is defined by

$$
J D_{\mathrm{h}}=i_{\mathrm{GDD}}=T_{\mathrm{h}},
$$

with $i_{\mathrm{GDD}=T_{\mathrm{h}}}$ being the iterator $i$ of growing degree days (GDD) reaching the threshold $\left(T_{\mathrm{h}}\right)$. Growing degree days is determined as:

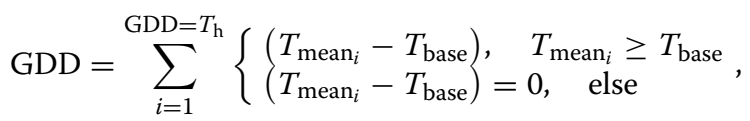

where $T_{\text {mean }}, T_{\text {base }}$ and $T_{\mathrm{h}}$ are the daily mean daily temperature, base temperature $\left(T_{\text {base }}=2.5{ }^{\circ} \mathrm{C},[15]\right.$ : root growth $\left(3{ }^{\circ} \mathrm{C}\right)$ and shoot growth $\left.\left(2{ }^{\circ} \mathrm{C}\right)\right)$, and threshold temperature as a fit parameter. The same value $\left(T_{\mathrm{h}}=2100{ }^{\circ} \mathrm{C}\right)$ was used for both study sites. We determined-based on harvest and sowing date-the vegetation days $\left(V_{\text {day }}\right)$ as the number of days with temperatures above base temperature during growing period $\left(V_{\mathrm{per}}\right)$. Therefore, we derived the equation

$$
\mathrm{DD}_{M}=\sum_{j=J D_{\mathrm{s}}}^{J D_{\mathrm{h}}} \begin{cases}V_{\text {Day }}+0, & T_{\mathrm{MAV}_{j}}>T_{\text {base }} \\ V_{\text {Day }}+0, & \text { else }\end{cases}
$$

where $T_{\mathrm{MAV}}$ denotes the simple moving average of the mean daily temperature given by

$T_{\mathrm{MAV}_{n}}=\frac{T_{\mathrm{MAV}_{(n-2)}}+T_{\mathrm{MAV}_{(n-1)}}+T_{\mathrm{MAV}_{n}}+T_{\mathrm{MAV}_{(n+1)}}+T_{\mathrm{MAV}_{(n+2)}}}{n}$

Iterators are $j$ and $n$.

\section{Time slots}

Time period analysed within this study is from 1981 until 2070. Within this period we selected two representative time slots of 30 years each. First slot is from 1981 to 2010 representing the status quo and delineates the reference period. The second slot is from 2041 to 2070 representing the future. Differences between the time slots indicate a possible climate change.

\section{Climate-recent climate}

Scenario weather data for representative weather stations are available with daily values for the model regions in the NGP. These data are the result of fitting "Statistical regionalization model: STAR" [13] to recent measured data of the appropriate weather stations. STAR scenario data (SCEN: 1981-2010) then match the observed values for each study area in terms like mean monthly precipitation, temperature and solar radiation. To exclude model 

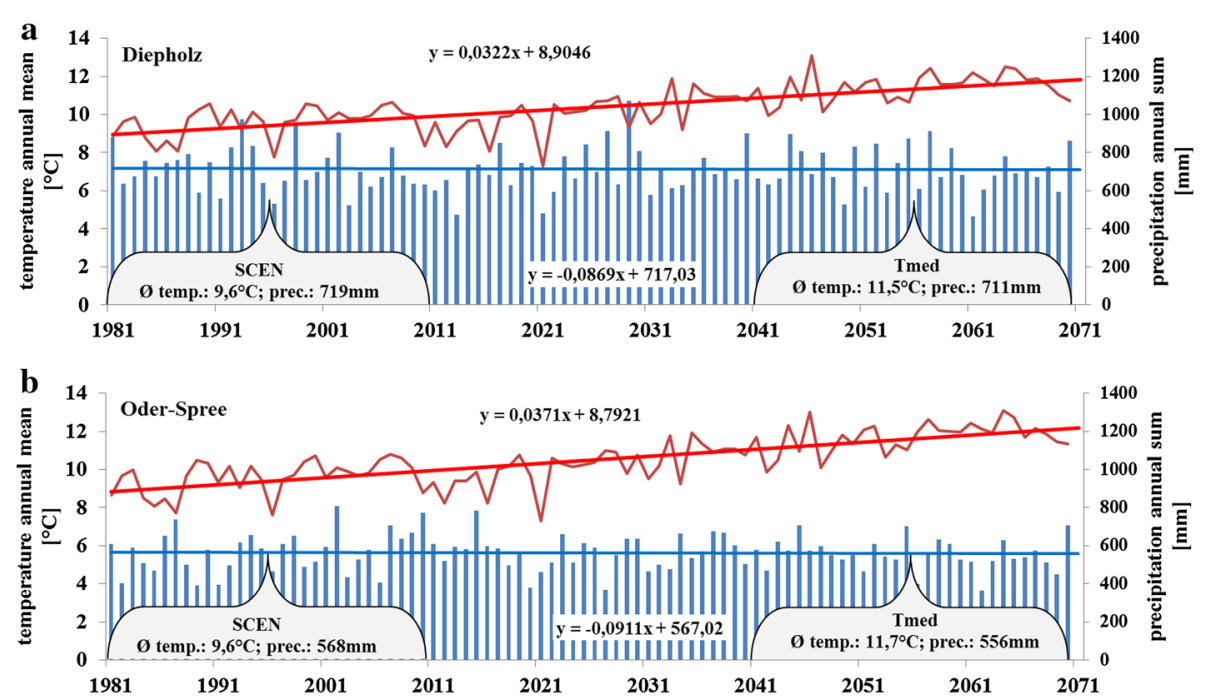

Fig. 2 Mean annual temperature (temp.) and sum of annual precipitation (prec.) of both study areas Diepholz (a top) and Oder-Spree (b bottom). Mean temperature and precipitation during the investigation period SCEN (1981-2010) as well as $T_{\text {med }}$ (2041-2070) is given

bias when comparing status quo with future climate data, all following evaluations of the status quo were based on the scenario (SCEN) climate data.

\section{Climate-climate change (CC) scenarios for future climate prediction}

The results for the current condition were compared to projected weather data driven by the output of general circulation models (GCM) run under representative concentration pathway 8.5 (RCP 8.5). Collective climate models were used for analysis and prediction of climate change. Collective climate models include $21 \mathrm{GCM}$; all were driven by the scenario RCP 8.5. For the present study, we have selected 3 out of $21 \mathrm{GCM}$ on the basis of their temperature gradient: (a) Minimum mean temperature increase $\left(T_{\min } \rightarrow \mathrm{INM}-\mathrm{CM} 4\right.$, Russia, $+1{ }^{\circ} \mathrm{C}$ until 2070). (b) Medium mean temperature increase $\left(T_{\text {med }} \rightarrow\right.$ ECHAM6, MPI Hamburg, Germany, $+2{ }^{\circ} \mathrm{C}$ ). (c) Maximum mean temperature increase $\left(T_{\max } \rightarrow\right.$ ACCESS1.0, CSIRO-BOM, Australia, $+3{ }^{\circ} \mathrm{C}$ ). The regionalisation of the GCM output was realised by the STAR model.

First of all, we need to define which aspects of climate change are relevant concerning crop production in general. Thus, in this study, the relevant climate change intends relevant for cropping winter wheat and includes in particular evaluations during the growing period and this period in parts.

Winter rainfall in our context is defined by DIN 4049 where the hydrological year $\left(H_{\mathrm{a}}\right)$ runs from 1 November of year one to 31 October of the following year. The winter season includes the months of November to April; the summer season includes the months of May to October.
The second benefit is the start and end of hydrological winter $\left(H_{\mathrm{W}}\right)$ that reflects start and end of leaching period in the NGP. Calculating this way enables us to analyse the winter rainfall during the typical leaching period and the summer rainfall from the end of the leaching period during summer until the harvest date, respectively.

Since rainfall during the growing period $\left(P_{\text {veg }}\right)$ is not a meaningful parameter for analysing possible water deficit of winter wheat, we introduced the precipitation during main growing period $\left(P_{\mathrm{m} \text {-veg }}\right)$ as a parameter of interest (beginning of possible water deficit due to emptying the soil water storage with the beginning of hydrological summer); $P_{\mathrm{m} \text {-veg }}$ is defined by the amount of precipitation measured from May 1 (assumed end of leaching period due to the beginning of significant transpiration) until harvest date.

\section{Statistical analysis}

All data were evaluated using the $\mathrm{R}$ software package $\mathrm{R}$ Core Team [16].

\section{Results \\ Model fit}

Pre-tests showed that, the regional data (scenario) agree with respect to their general temperature trend, their variability and their precipitation with the climate data of the weather stations (observed) in the regions (data not shown). Harvest dates were reasonably well predicted by our simple model. The mean observed harvest dates of the study region Diepholz over 21 years were day 216 while the model underestimates by 3 days. The same good model fit could be shown for the Oder-Spree region where the observed mean harvest date was 214 
and the modelled was 214 . Annually simulated as well as observed harvest dates are presented in Fig. 3a, b.

\section{Shift towards winter rainfall}

The mean precipitation during the hydrological year $\left(H_{\mathrm{a}}\right.$ : 1 May until 31 April) for the reference period (SCEN: 1981-2010) is $705 \mathrm{~mm}$ for DH and is $566 \mathrm{~mm}$ for OS. In the future (2041-2070) precipitation during $H_{\mathrm{a}}$ ranges between 683 and $711 \mathrm{~mm}$ for DH and between 512 and $570 \mathrm{~mm}$ for OS depending on the scenario $\left(T_{\text {min }}, T_{\text {med }}\right.$, $\left.T_{\max }\right)$. Thus, there is no significant change in annual precipitation while comparing the reference with the future period. Compared to the very little alteration of total amount of precipitation, standard deviation (as an indicator of constancy) of mean precipitation decreases in DH from 122 (SCEN) to 97 ( $\left.T_{\text {med }}\right)$ and in OS from 101 (SCEN) to $67\left(T_{\text {med }}\right)$ when comparing recent with future time period (Table 1). Mean precipitation during hydrological winter $\left(H_{\mathrm{W}}\right)$ during the SCEN period is $331 \mathrm{~mm}$ in $\mathrm{DH}$ and $246 \mathrm{~mm}$ in OS. Within the future time slot $T_{\text {med }} \mathrm{DH}$ has a mean $H_{\mathrm{W}}$ precipitation of $387 \mathrm{~mm}$ and OS $296 \mathrm{~mm}$, respectively. The share of precipitation during $H_{\mathrm{W}}\left(H_{\mathrm{a}} / H_{\mathrm{W}}\right)$ in the SCEN period is for DH 0.47 and for OS 0.44 and for the future time slot in $T_{\text {med }}$ for DH 0.54 and for OS 0.53. The scenario $T_{\max }$ delivered comparable results, while in the $T_{\min }$ scenario the share ranges between $0.50(\mathrm{DH})$ and $0.48(\mathrm{OS})$.

\section{Harvest date}

The mean harvest date within the SCEN period lies between the 3 and 5 August while for the $T_{\text {med }}$ period earlier dates between 3 July and 30 June were calculated (Fig. 4a, b). Evaluating $T_{\min }$, the harvest date is earlier than in SCEN but later than $T_{\text {med }}$ (13 and 14 July). Much earlier is the $H_{\text {day }}$ when dealing with the $T_{\max }: 19$ and 21 June.

\section{Growing period}

Length of the growing period is strongly correlated with the harvest date. The growing period of winter wheat $\left(V_{\text {per }}\right)$ during the reference period (SCEN) is 324 days in $\mathrm{DH}$ and 323 days in OS while the vegetation days during the $V_{\text {per }}$ is 267 in DH and 246 in OS (Table 2). Therefore, in $\mathrm{DH} 57$ cold days (days with less than $2.5^{\circ} \mathrm{C}$ within the $V_{\text {per }}$ as an indicator for the frequency of the interruption of biomass accumulation) and in OS 77 cold days were detected during the 1981-2010 period. In the future (2041-2070) period ( $T_{\mathrm{med}}$ ) the $V_{\mathrm{per}}$ is shorter by 33 days and 34 days in DH and OS, respectively, when compared to SCEN. The cold days in the $T_{\min }$ were reduced to 30
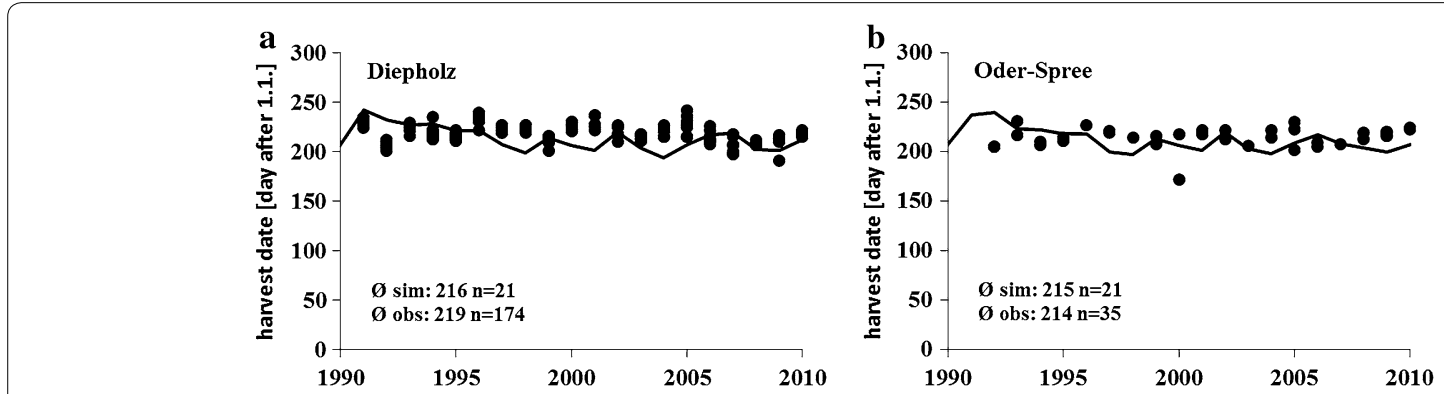

Fig. 3 Observed and modelled harvest dates for the study region Diepholz (a left) and Oder-Spree (b right) for the time period $1991-2010$ (phenological data were provided by the German Weather Service DWD)

Table 1 Precipitation in the study regions Diepholz (DH) and Oder-Spree (OS) differentiated according to annual precipitation (1.1.-31.12.), precipitation during hydrological year (1.10.-31.9.), hydrological winter (1.10.-31.4.) and the share of precipitation during hydrological winter $\left(H_{\mathrm{w}}\right)$

\begin{tabular}{|c|c|c|c|c|c|c|c|c|}
\hline & \multicolumn{2}{|c|}{ Annual precipitation } & \multicolumn{2}{|c|}{ Hydrological year } & \multicolumn{2}{|c|}{ Hydrological winter } & \multicolumn{2}{|c|}{ Share of $H_{w}$} \\
\hline & SCEN & $T_{\text {med }}$ & SCEN & $T_{\text {med }}$ & SCEN & $T_{\text {med }}$ & SCEN & $T_{\text {med }}$ \\
\hline \multicolumn{9}{|l|}{$\mathrm{DH}$} \\
\hline$P(\mathrm{~mm})$ & 709 & 711 & 705 & 711 & 331 & 387 & 0.47 & 0.54 \\
\hline$S D(\mathrm{~mm})$ & 132 & 112 & 122 & 97 & 63 & 50 & & \\
\hline \multicolumn{9}{|l|}{ OS } \\
\hline$P(\mathrm{~mm})$ & 572 & 556 & 566 & 556 & 246 & 296 & 0.44 & 0.53 \\
\hline $\mathrm{SD}(\mathrm{mm})$ & 104 & 80 & 101 & 67 & 55 & 43 & & \\
\hline
\end{tabular}

SCEN represents the recent time period (1981-2010), $T_{\text {med }}$ the future time period (2041-2070), SD is the standard deviation 

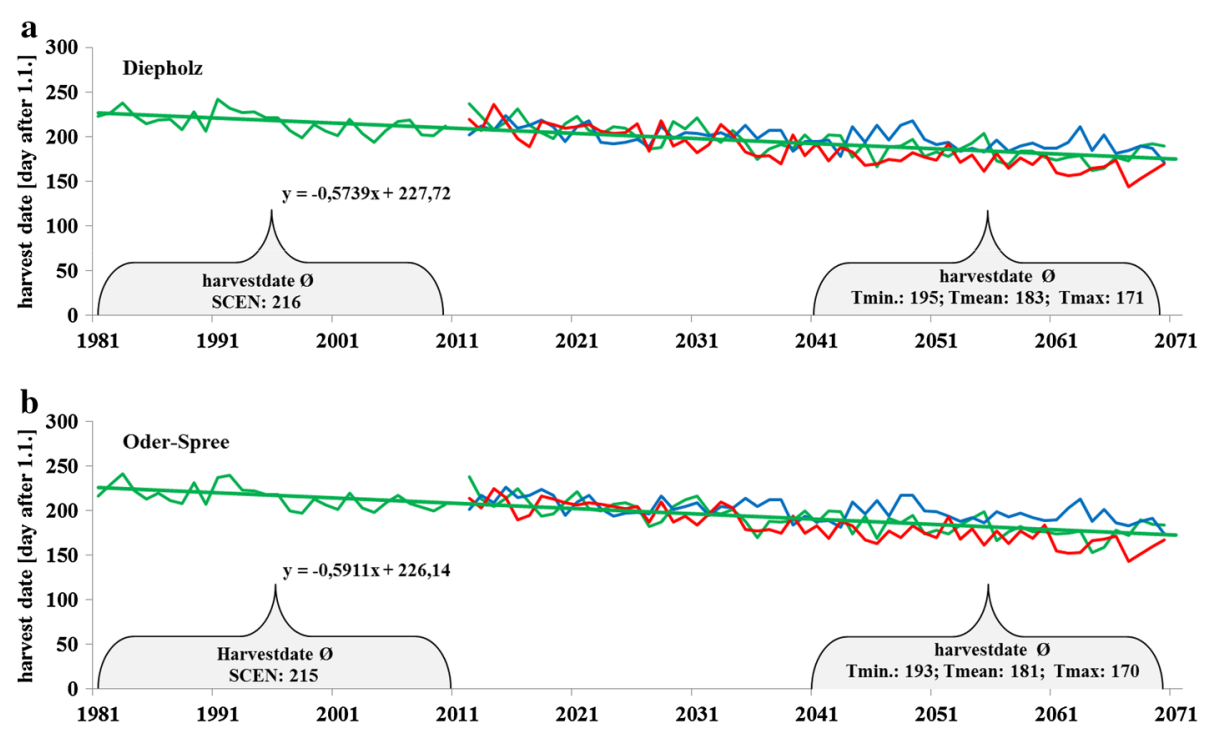

Fig. 4 The harvest date as expressed in Julian days after 1 January for the study region Diepholz (a top) and Oder-Spree (b bottom). Future harvest dates were calculated on the basis of $T_{\min }\left(\right.$ blue), $T_{\text {med }}$ (green) and $T_{\max }($ red $)$ scenario. Linear trend is given for the SCEN and $T_{\text {med }}$ Scenario

Table 2 Growing period (days) of winter wheat $\left(V_{\text {per }}\right)$ as defined by the delimiters sowing and harvest date for the study regions Diepholz (DH) and Oder-Spree (OS)

\begin{tabular}{lll}
\hline & SCEN & $T_{\text {med }}$ \\
\hline $\mathrm{DH}$ & & \\
$V_{\text {per }}$ & 324 & 291 \\
$V_{\text {day }}$ & 267 & 261 \\
OS & & \\
$V_{\text {per }}$ & 323 & 289 \\
$V_{\text {day }}$ & 246 & 246 \\
\hline
\end{tabular}

SCEN represents the recent time period (1981-2010), $T_{\text {med }}$ the future time period (2041-2070)

(DH) and 42 (OS). Within the $T_{\max }$ a minimum of cold days of $19(\mathrm{DH})$ and 30 (OS) was counted.

Rainfall during main growing period and potential drought During the main growing period $\left(P_{\mathrm{m} \text {-veg: }} 1\right.$ May until harvest) $197 \mathrm{~mm}$ were measured in $\mathrm{DH}$ and $171 \mathrm{~mm}$ in OS, Table 3). For the $T_{\text {med }}$ scenario less rainfall during $P_{\mathrm{m} \text {-veg }}$ 115 to $98 \mathrm{~mm}$ was calculated (Fig. 5a, b). Similar results for $P_{\mathrm{m} \text {-veg }}$ can be shown for $T_{\min }$ (149 $\mathrm{mm}$ in $\mathrm{DH}$ and $136 \mathrm{~mm}$ in OS) and for $T_{\max }(78 \mathrm{~mm}$ in $\mathrm{DH}$ and $68 \mathrm{~mm}$ in OS).

\section{Discussion \\ Model fit}

When comparing the data from the weather stations during the reference period with the modelled STAR outcome no significant differences are noticed. This is in
Table 3 Precipitation during main growing period $\left(\boldsymbol{P}_{\mathrm{m} \text {-veg }}\right)$

\begin{tabular}{lcc}
\hline & SCEN & $\boldsymbol{T}_{\text {med }}$ \\
\hline $\mathrm{DH}$ & 197 & \\
$P_{\text {m-veg }}(\mathrm{mm})$ & & 115 \\
$\mathrm{OS}$ & 171 & 98 \\
$P_{\text {m-veg }}(\mathrm{mm})$ & 171 \\
\hline
\end{tabular}

SCEN represents the recent time period (1981-2010), $T_{\text {med }}$ the future time period (2041-2070)

good agreement of Gerstengarbe et al. [7] who compared STAR with the current climatology of selected regions all over Germany. Gallardo et al. [5] show similar results while analysing an ensemble of 15 regional climate models nested into six GCM. They found differences depending on the region and the investigated model. Our simple model for calculating the harvest date reasonably well predicts the mean harvest date over a long period of 30 years. For some years the prediction is less precise. For this reason, we have based all results to the long term.

\section{Shift towards winter rainfall}

The shift towards winter rainfall with $+7 \%$ in $\mathrm{DH}$ and $+9 \%$ in OS is less pronounced than reported in many studies $[9,11,12]$. That may be because of the different period (hydrological vs. calendric) selected on the one hand and the different period of time (1981-2010) in total. Badeck et al. [1] suggested that a fraction of uncertainty may arise due to the time frame analysed. Comparing the mean annual precipitation of calendric against hydrologic year in the present time period, $\mathrm{DH}$ 


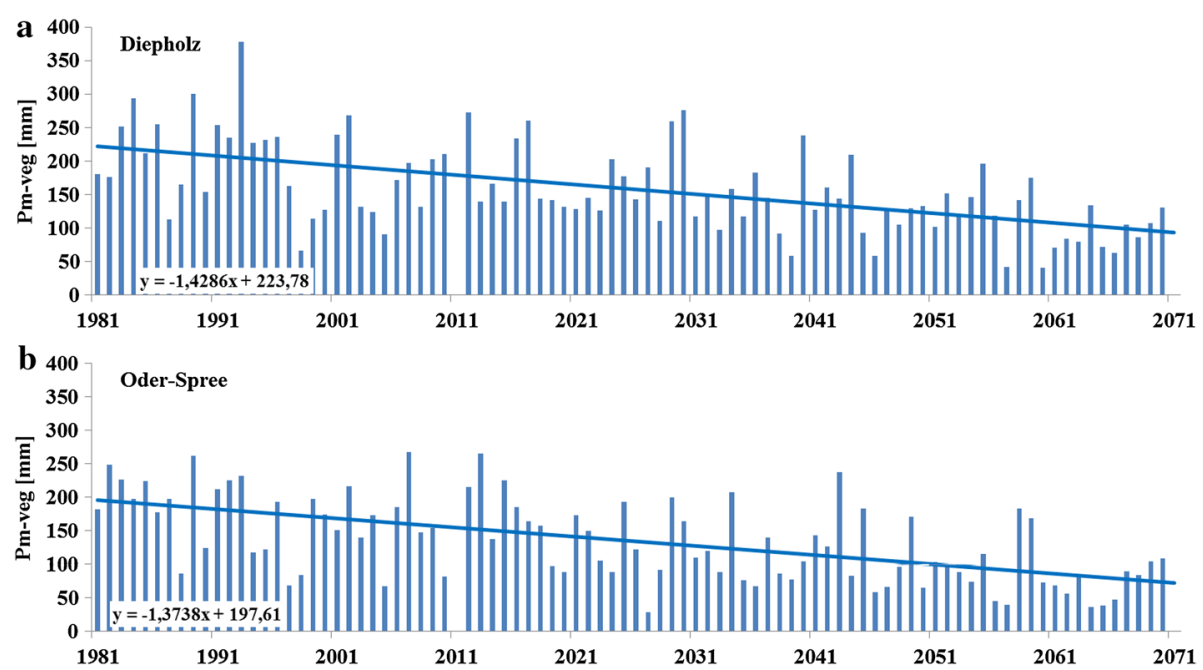

Fig. 5 Annual precipitation during main growing period from the beginning of summer until harvest for Diepholz (a top) and Oder-Spree (b bottom)

shows with $709 \mathrm{~mm}$ compared to $711 \mathrm{~mm}$ only little difference. However, OS reflects similar results on a lower level (572 to $566 \mathrm{~mm}$ ). Kozuchowski and Degirmendizc [10] analysed long time weather data in different regions in Poland and found that regional differences are widespread. Following this, it may be possible, that the regions investigated in the present study may have a different shift than the mean of the NGP. Further studies should clarify the situation.

\section{Harvest date}

Patil et al. [14] found evidence that increased temperature led to earlier harvest date; the same effect we discovered for both regions. Depending on the scenario $\left(T_{\text {min }}\right.$, $\left.T_{\text {med }}, T_{\max }\right)$ the harvest date will be three $\left(T_{\min }\right)$, five ( $\left.T_{\text {med }}\right)$ or six $\left(T_{\max }\right)$ weeks earlier than today. For Southern Sweden, Eckersten [6] has also found earlier harvest dates for winter wheat along with rising temperatures, while the yields stayed the same or decreased.

\section{Growing period and rainfall during growing period}

While comparing the growing period of winter wheat $\left(V_{\text {per }}\right)$ in SCEN (1981-2010) with the $V_{\text {per }}$ in $T_{\max }$ (2041-2070), there is a reduction of 45 (14\%) days in both regions. These findings correspond with Brown and Rosenberg [3] who calculated the length of the growing season of winter wheat in North America with different GCM. They pointed out that with increasing temperature the potential of water stress may arise. Reciprocal to the growing days we calculated the so-called cold days, with less than $2.5{ }^{\circ} \mathrm{C}$, during the growing period. The amount of cold days decreased by $>60 \%$ to 19 days in the $T_{\max }$ scenario. Walther et al. [19] discovered a comparable trend for frost days when analysing recent data of southern Switzerland. This could be relevant for vernalisation. Porter and Gawith [15] reported the optimal temperature for vernalisation process of winter wheat is between 3.8 and $6.0{ }^{\circ} \mathrm{C}$, while in this study $2.5^{\circ} \mathrm{C}$ [18] was taken to define cold days. Further regional adopted climate evaluations have to take care of optimal parameters. Under current conditions, $32 \%(\mathrm{DH})$ to $36 \%(\mathrm{OS})$ of the precipitation within the growing period comes during the main growing period from beginning of hydrological summer to harvest date. We observed a distinct shift of the precipitation towards the period in which the wheat plant does not require a lot of water (sowing until $1 \mathrm{March}$ ).

\section{Conclusion and outlook}

It became clear that there is a relevant difference comparing the status quo with current climate projections for the NPG. We found clear indications that the available precipitation during main growing period of winter wheat will decrease. Effects on yield have to be investigated using an appropriated plant soil model. While total annual rainfall does not change significantly a strong shift towards winter precipitation becomes evident. Possible consequences (e.g. nutrient leaching, erosion, need of introduction of catch crops) have to be evaluated in further studies.

\section{Authors' contributions}

NS developed the design of the model and the study in total, evaluated the results and drafted the manuscript. JH participated in the study, coordinated and helped to draft the manuscript. MS participated in the design of the study and performed R coding. All authors read and approved the final manuscript. 


\section{Acknowledgements}

This project was supported by the German Ministry of Research (BMBF). Project: NaLaMa-nT, FKZ 033L029. The PIK (Potsdam Institute for Climate Impact Research) is gratefully acknowledged for providing the climate data.

\section{Competing interests}

The authors declare that they have no competing interests.

Received: 19 May 2015 Accepted: 29 October 2015

Published online: 10 November 2015

\section{References}

1. Badeck FW, Bondeau A, Böttcher K, Doktor D, Lucht W, Schaber J, Sitch S (2004) Responses of spring phenology to climate change. New Phytologist 162:295-309

2. Boogaard H, Wolf J, Supit I, Nimeyer S, van Ittersum M (2013) A regional implementation of WOFOST for calculating yield gaps of autumn-sown wheat across the European Union. Field Crop Res 143:130-142

3. Brown R, Rosenberg N (1999) Climate change impacts on the potential productivity of corn and winter wheat in their primary United States growing regions. Climatic Change 41:73-107

4. Dickinson RE (1961) A general and regional geography. E. P. Dutton and Company, Germany

5. Gallardo C, Gil V, Hagel E, Tejeda C, de Castro M (2013). Assessment of climate change in Europe from an ensemble of regional climate models by the use of Köppen - Trewartha classification. Int J Climatol

6. Eckersten $\mathrm{H}$ (2011). Climate change scenarios, crop production, length of growing period. Risk assessment/risk management, forecasting pests and diseases of field crops in a changing climate-Control strategies for pests, diseases and weeds

7. Gerstengarbe FW, Werner P, Österle H, Burghoff O (2013) Winter stormand summer thunderstorm-related loss events with regard to climate change in Germany. Theor Appl Climatol 114:715-724

8. Goudriaan I, Laar HV (1994) Modelling potential crop growth processes textbook with exercises. Kluwer Acad. Publishers, Dordrecht
9. Grimm NB, Chapin FS, Bierwagen B, Gonzalez P, Groffman PM, Luo Y, Melton F, Nadelhoffer K, Pairis A, Raymond PA, Schimel J, Williamson CE (2013) The impacts of climate change on ecosystem structure and function. Frontiers Ecol Environ 11:474-482

10. Kozuchowski K, Degirmendzic J (2005) Contemporary changes of climate in Poland: trends and variation in thermal and solar conditions related to plant vegetation. Pol J Ecol 53:283-297

11. Lotze-Campen HCLDA, Noleppa S, Rock J, Schuler J, Uckert G (2009). Klimawandel und Kulturlandschaft Berlin. Technical report, Senatsverwaltung für Stadtentwicklung, Abteilung I, Gemeinsame Landesplanung Berlin-Brandenburg, Berliner Forsten, Berliner Stadtgüter $\mathrm{GmbH}$

12. Meinke I, Gerstner E, von Storch H, Marx A, Schipper H, Kottmeier C, Treffeisen R, Lemke P (2010) Regionaler Klimaatlas Deutschland der Helmholtz-Gemeinschaft informiert im Internet über möglichen künftigen Klimawandel. Mitteilungen DMG, 02/2010, pp 5-7. http://www. norddeutscher-klimaatlas.de/klimaatlas/2071-2100/jahr/durchschnittliche-temperatur/norddeutschland.html (in German). Accessed 05 Aug 2015

13. Orlowsky B, Gerstengarbe F-W, Werner PC (2008) A resampling scheme for regional climate simulations and its performance compared to a dynamical RCM. Theor Appl Climatol 92:209-223

14. Patil RH, Laegdsmand M, Olesen JE, Porter JR (2010) Growth and yield response of winter wheat to soil warming and rainfall patterns. J Agric Sci 148:553-566

15. Porter JR, Gawith M (1999) Temperatures and the growth and development of wheat: a review. Eur J Agron 10:23-36

16. R Core Team (2013) R: A language and environment for statistical computing. Vienna, Austria, R Foundation for Statistical Computing. Available at http://www.R-project.org. Accessed 05 Aug 2015

17. Tubiello FN, Soussana J-F, Howden SM (2007) Crop and pasture response to climate change. Proc Natl Acad Sci 104:19686-19690

18. Waloszczyk K (1995) Einfluss von Lufttemperatur und Bestandesdichte auf das Wachstum von Winterweizen von Aufgang bis Vegetationsbeginn im Frühjahr. Arch Agron Soil Sci 39:379-387

19. Walther GR, Post E, Convey P, Menzel A, Parmesan C, Beebee TJC, Fromentin JM, Hoegh-Guldberg O, Bairlein F (2002) Ecological responses recent climate change. Nature 416:389-395

\section{Submit your manuscript to a SpringerOpen ${ }^{\circ}$ journal and benefit from:}

- Convenient online submission

- Rigorous peer review

- Immediate publication on acceptance

- Open access: articles freely available online

- High visibility within the field

- Retaining the copyright to your article

Submit your next manuscript at $>$ springeropen.com 